\title{
Impact of on farm trials (OFT) on agro-technology for sustainable productivity of rice-utera cropping system in Chhattisgarh plains
}

\author{
V.A. VIKHE, T.B. CHAVAN, N.S. DALE, R.B. UMBARKAR AND V.N. ANAP
}

Received : 05.05.2014; Revised : 03.08.2014; Accepted : 15.08.2014

\begin{abstract}
The research work was conducted in ten rainfed villages of Mahasamund and Rajnandgaon district of Chhattisgarh state, where the project work (NATP-RRPS-34) was carried out. A total of 12 farmers practicing rice-utera cropping system from each selected village were selected randomly. In this way, a total of 120 farmers were taken as respondents. The data were collected through personal interview method. The findings of the study revealed that, the On farm trials in rice-utera cropping system were helpful in increasing the yield. The other important perceptions about OFTs were dissemination of technology and variety replacement. The trends of cultivation of rice varieties before and after OFTs showed that Mahamaya, HMT, MTU-1010 were gaining more area. The high yielding dwarf rice varieties were gaining popularity over traditional varieties. The impact of OFTs on productivity showed that the rice yield was increased followed by Lathyrus. It indicates that due to implementation of OFTs the average yield of rice as well as utera crops was increased significantly. The impact of OFTs on productivity showed that rice yield was increased by more than 58 per cent and maximum 140.9 per cent increase was recorded in grasspea followed by 108.33 per cent in lentil. It indicates that the high yielding dwarf rice varieties were gaining popularity over traditional varieties and the average yield of rice as well as utera crops was increased significantly. Therefore, it is recommended for profitable rice-utera system, proper crop management practices should be initiated from rice to utera crops.
\end{abstract}

KEY WORDS : OFT, Rice-utera, Agrotechnology

How to cite this paper : Vikhe, V.A., Chavan, T.B., Dale, N.S., Umbarkar, R.B. and Anap, V.N. (2014). Impact of on farm trials (OFT) on agro-technology for sustainable productivity of rice-utera cropping system in Chhattisgarh plains. Internat. J. Com. \& Bus. Manage, 7(2) : 265-268.

\section{MEMBERS OF THE RESEARCH FORUM}

Correspondence to:

V.A. VIKHE, College of Agriculture Business Management, Loni, AHMEDNAGAR (M.S.) INDIA

Email: vijay_vikhe@ rediffmail.com

\section{Authors' affiliations:}

T.B. CHAVAN, Krishi Vigyan Kendra, Gandheli, AURAngABAD (M.S.) INDIA

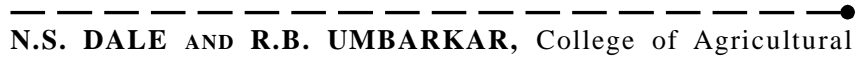

Biotechnology, Loni, AHMEDNAGAR (M.S.) INDIA

V.N. ANAP, College of Agriculture Business Management, Loni, AHMEDNAGAR (M.S.) INDIA 